\title{
Sesquiterpene Esters from the Fruits of Celastrus orbiculatus
}

\author{
Yuan Qiang Guo, Xian Li,* Jing Xu, Ning Li, Da Li Meng, and Jin Hui Wang \\ Research Department of Natural Medicine, Shenyang Pharmaceutical University; Shenyang 110016, P. R. China. \\ Received April 13, 2004; accepted May 27, 2004
}

Three new $\beta$-dihydroagarofuran sesquiterpene esters, $6 \alpha$-acetoxy-9 $\beta$-benzoyloxy-1 $\beta$-cinnamoyloxy-8 $\beta$-butanoyloxy- $\beta$-dihydroagarofuran (1), $6 \alpha$-acetoxy-9 $\beta$-benzoyloxy- $1 \beta$-cinnamoyloxy-8 $\beta$-(2-methylbutanoyloxy)- $\beta$-dihydroagarofuran (2), and $6 \alpha$-acetoxy-1 $\beta, 8 \beta$-dibenzoyloxy-9 $\beta$-hydroxy- $\beta$-dihydroagarofuran (6), together with three known compounds (3-5) were isolated from the fruits of Celastrus orbiculatus Thunb. Their structures were elucidated on the basis of spectroscopic methods. Compound 4 showed moderate activity in inhibiting LPSinduced nitric oxide production in murine macrophage RAW264.7 cells with an $\mathrm{IC}_{50}$ value of $43.7 \mu \mathrm{M}$.

Key words Celastrus orbiculatus; sesquiterpene ester; $\beta$-dihydroagarofuran

Celastrus orbiculatus is a medicinal plant widely distributed in China, which acts as a tranquilizer. ${ }^{1)}$ Some sesquiterpenes with antiinflammatory activities from $C$. orbiculatus were reported in the literature. ${ }^{2)}$ To find the active constituents responsible for antiinflammation, we investigated the constituents of the fruits. Three new $\beta$-dihydroagarofuran sesquiterpene esters, $6 \alpha$-acetoxy- $9 \beta$-benzoyloxy- $1 \beta$-cinnamoyloxy- $8 \beta$-butanoyloxy- $\beta$-dihydroagarofuran (1), $6 \alpha$ acetoxy-9 $\beta$-benzoyloxy- $1 \beta$-cinnamoyloxy- $8 \beta$-(2-methylbutanoyloxy)- $\beta$-dihydroagarofuran (2), and $6 \alpha$-acetoxy- $1 \beta, 8 \beta$ dibenzoyloxy- $9 \beta$-hydroxy- $\beta$-dihydroagarofuran (6) were isolated, along with three known compounds, $6 \alpha$-acetoxy$1 \beta, 8 \beta, 9 \beta$-tribenzoyloxy- $\beta$-dihydroagarofuran (3), $1 \beta, 2 \beta$-diacetoxy- $6 \alpha$-benzoyloxy-9 $\alpha$-cinnamoyloxy- $\beta$-dihydroagarofuran (4), and $1 \beta, 6 \alpha$-diacetoxy- $8 \beta, 9 \beta$-dibenzoyloxy- $\beta$-dihydroagarofuran (5). In this paper, we elucidate the structures of $\mathbf{1}, \mathbf{2}$, and $\mathbf{6}$ and the effects of compounds $\mathbf{1}-\mathbf{6}$ on nitric oxide (NO) production in lipopolysaccharide-stimulated murine macrophage RAW264.7 cells. Compound 4 showed moderate inhibitory activity against LPS-induced NO production in murine macrophage RAW264.7 cells, with $\mathrm{IC}_{50}$ values of $43.7 \mu \mathrm{M}$ with respect to aminoguanidine, an inducible NOS inhibitor ( $\left.\mathrm{IC}_{50} 18.2 \mu \mathrm{M}\right)$.

\section{Results and Discussion}

The fruits of $C$. orbiculatus were extracted with $95 \%$ ethanol and partitioned successively with petroleum ether, $\mathrm{CHCl}_{3}, \mathrm{EtOAc}$, and $n$-BuOH. The petroleum ether fraction $(160 \mathrm{~g})$ was subjected to column chromatography on Silica gel and PHPLC to provide compounds 1-6. The known compounds $\mathbf{3}, \mathbf{4}$, and $\mathbf{5}$ were identified by comparison of their physical and spectral data with those reported in the litera-

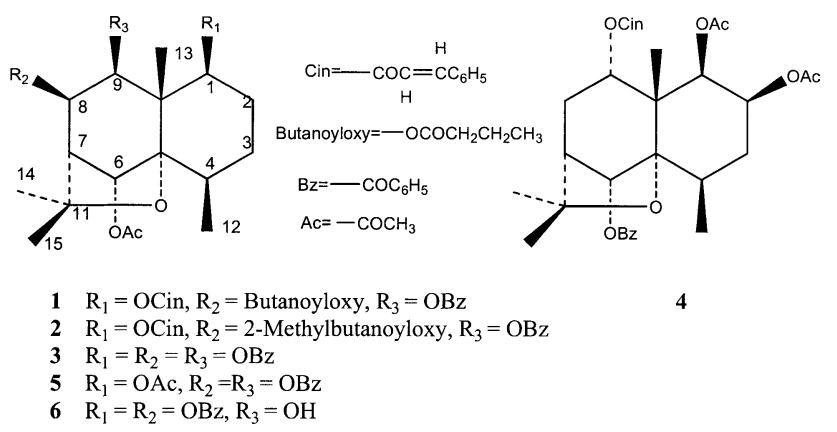

ture. $^{3-5)}$

Compound 1 was obtained as a white powder. The HR-MS spectrum suggested a molecular formula of $\mathrm{C}_{37} \mathrm{H}_{44} \mathrm{O}_{9}$ for $\mathbf{1}$. The UV (MeOH) spectrum of $\mathbf{1}$ showed the presence of aromatic rings. The ${ }^{1} \mathrm{H}$ - and ${ }^{13} \mathrm{C}-\mathrm{NMR}$ spectra revealed the presence of one benzoyloxy group, one cinnamoyloxy group, one acetoxy group, and one butanoyloxy group. In addition, the ${ }^{13} \mathrm{C}-\mathrm{NMR}$ spectrum indicating the remaining parent compound consisted of 15 carbons: four methyl $(\delta 16.9,12.1$, $24.1,30.6)$, two methylene carbons $(\delta 22.2,26.6)$, six methine carbons $(\delta 33.8,52.5,71.2,75.1,74.3,78.9)$, and three quaternary carbons $(\delta 48.9,81.7,91.0)$. These ${ }^{13} \mathrm{C}-\mathrm{NMR}$ data were very similar to those assigned to $1,6,8,9$-tetra-substituted $\beta$-dihydroagarofuran., ${ }^{3,6)}$ Therefore compound $\mathbf{1}$ had four ester groups linked at C-1, C-6, C-8, and C-9.

The ester group distribution in $\mathbf{1}$ was determined from the HMBC spectrum, which showed cross peaks between H-6 $[\delta$ $5.93(1 \mathrm{H}, \mathrm{s})]$ and the carbonyl $(\delta 169.9)$ of acetoxy, H-1 [ $\delta$ $5.37(1 \mathrm{H}, \mathrm{dd}, J=11.1,4.9 \mathrm{~Hz})]$ and the carbonyl $(\delta 166.1)$ of cinnamoyloxy, H-8 $[\delta 5.54(1 \mathrm{H}, \mathrm{dd}, J=5.2,4.2 \mathrm{~Hz})]$ and the carbonyl ( $\delta 172.4)$ of butanoyloxy, and H-9 $[\delta 5.61(1 \mathrm{H}, \mathrm{d}$, $J=5.2 \mathrm{~Hz})]$ and the carbonyl ( $\delta$ 164.9) of benzoyloxy, respectively. These results showed that the acetoxy was situated at C-6, while cinnamoyloxy, butanoyloxy, and benzoyloxy were at C-1, C-8, and C-9, respectively. Generally, H-1 and H-6 have axial stereochemistry in this class of compounds. ${ }^{6,7)}$ The NOESY spectrum showed cross peaks between $\mathrm{H}_{\mathrm{ax}}-1$ and $\mathrm{H}-9$, and $\mathrm{H}-8$ and $\mathrm{H}-9$, which suggests the orientation of axial H-9 and equatorial H-8. ${ }^{3,5-7)}$ Thus the structure of 1 was elucidated to be $6 \alpha$-acetoxy- $9 \beta$-benzoyloxy- $1 \beta$-cinnamoyloxy- $8 \beta$-butanoyloxy- $\beta$-dihydroagarofuran.

Compound 2 was $\mathrm{C}_{38} \mathrm{H}_{46} \mathrm{O}_{9}$ based on the HR-MS spectrum. The UV, ${ }^{1} \mathrm{H}$ - and ${ }^{13} \mathrm{C}$-NMR spectra showed the presence of one acetoxy, one cinnamoyloxy, one 2-methylbutanoyloxy, and one benzoyloxy groups. The ${ }^{1} \mathrm{H}$ - and ${ }^{13} \mathrm{C}$ NMR spectra of $\mathbf{1}$ and $\mathbf{2}$ were very similar except for the ester moieties, which indicates that the position of the ester function was at C-1, C-6, C-8, and C-9. The HMBC spectrum showed cross peaks between $\mathrm{H}-1[\delta 5.38(1 \mathrm{H}$, dd, $J=10.8,5.3 \mathrm{~Hz})]$ and the carbonyl $(\delta 166.1)$ of cinnamoyloxy, H-6 $[\delta 5.94(1 \mathrm{H}, \mathrm{s})]$ and the carbonyl ( $\delta$ 169.8) of acetoxy, H-8 $[\delta 5.56(1 \mathrm{H}, \mathrm{dd}, J=5.2,4.2 \mathrm{~Hz})]$ and the carbonyl $(\delta 175.2)$ of 2-methylbutanoyloxy, and H-9 $[\delta 5.63(1 \mathrm{H}, \mathrm{d}$, $J=5.2 \mathrm{~Hz}$ ) ] and the carbonyl ( $\delta 164.8)$ of benzoyloxy, which 
Table 1. NMR Data for Compounds $\mathbf{1}, \mathbf{2}$, and $\mathbf{6}$ in $\mathrm{CDCl}_{3}(\delta \mathrm{ppm})$

\begin{tabular}{|c|c|c|c|c|c|c|}
\hline \multirow{2}{*}{ No. } & \multicolumn{2}{|c|}{1} & \multicolumn{2}{|c|}{2} & \multicolumn{2}{|c|}{6} \\
\hline & $\delta_{\mathrm{C}}$ & $\delta_{\mathrm{H}}$ & $\delta_{\mathrm{C}}$ & $\delta_{\mathrm{H}}$ & $\delta_{\mathrm{C}}$ & $\delta_{\mathrm{H}}$ \\
\hline 1 & 78.9 & $\begin{array}{c}5.37 \mathrm{dd} \\
(11.1,4.9)\end{array}$ & 78.9 & $\begin{array}{c}5.38 \mathrm{dd} \\
(10.8,5.3)\end{array}$ & 79.6 & $\begin{array}{c}5.56 \mathrm{dd} \\
(10.8,5.0)\end{array}$ \\
\hline 2 & 22.2 & $1.75 \mathrm{~m}$ & 22.3 & $1.77 \mathrm{~m}$ & 22.3 & $1.79 \mathrm{~m}$ \\
\hline 3 & 26.6 & $\begin{array}{l}2.25 \mathrm{~m} \\
1.48 \mathrm{~m}\end{array}$ & 26.6 & $\begin{array}{l}2.20 \mathrm{~m} \\
1.50 \mathrm{~m}\end{array}$ & 26.7 & $\begin{array}{l}2.20 \mathrm{~m} \\
1.51 \mathrm{~m}\end{array}$ \\
\hline 4 & 33.8 & $2.25 \mathrm{~m}$ & 33.9 & $2.26 \mathrm{~m}$ & 33.8 & \\
\hline 5 & 91.0 & & 91.1 & & 91.0 & \\
\hline 6 & 75.1 & $5.93 \mathrm{~s}$ & 75.0 & $5.94 \mathrm{~s}$ & 75.1 & $6.04 \mathrm{~s}$ \\
\hline 7 & 52.5 & $\begin{array}{c}2.50 \mathrm{~d} \\
(4.2)\end{array}$ & 52.6 & $\begin{array}{c}2.49 \mathrm{~d} \\
(4.2)\end{array}$ & 52.5 & $\begin{array}{c}2.53 \mathrm{~d} \\
(4.2)\end{array}$ \\
\hline 8 & 71.2 & $\begin{array}{c}5.54 \mathrm{dd} \\
(5.2,4.2)\end{array}$ & 70.9 & $\begin{array}{c}5.56 \mathrm{dd} \\
(5.2,4.2)\end{array}$ & 74.1 & $\begin{array}{c}5.59 \mathrm{dd} \\
(5.0,4.2)\end{array}$ \\
\hline 9 & 74.3 & $\begin{array}{l}5.61 \mathrm{~d} \\
(5.2)\end{array}$ & 74.6 & $\begin{array}{c}5.63 \mathrm{~d} \\
(5.2)\end{array}$ & 73.2 & $\begin{array}{c}4.42 \mathrm{~d} \\
(5.0)\end{array}$ \\
\hline 10 & 48.9 & & 48.9 & & 49.0 & \\
\hline 11 & 81.7 & & 81.7 & & 81.3 & \\
\hline 12 & 16.9 & $\begin{array}{c}1.07 \mathrm{~d} \\
(7.5)\end{array}$ & 16.9 & $\begin{array}{c}1.08 \mathrm{~d} \\
(7.3)\end{array}$ & 16.8 & $\begin{array}{c}1.08 \mathrm{~d} \\
(7.4)\end{array}$ \\
\hline 13 & 12.1 & $1.57 \mathrm{~s}$ & 12.2 & $1.58 \mathrm{~s}$ & 11.3 & $1.46 \mathrm{~s}$ \\
\hline 14 & 24.1 & $1.58 \mathrm{~s}$ & 24.2 & $1.60 \mathrm{~s}$ & 24.1 & $1.49 \mathrm{~s}$ \\
\hline 15 & 30.6 & $1.42 \mathrm{~s}$ & 30.7 & $1.43 \mathrm{~s}$ & 30.7 & $1.43 \mathrm{~s}$ \\
\hline
\end{tabular}

Figures in parentheses are coupling constants in Hz. All signals were assigned using 1D and 2D NMR.

means that acetoxy, cinnamoyloxy, 2-methylbutanoyloxy, benzoyloxy were situated at C-6, C-1, C-8, and C-9, respectively. In the NOESY spectrum, cross peaks between $\mathrm{H}-1$ and H-8, and H-9 and H-8 suggested H-9 axial, and H-8 equatorial orientations. ${ }^{3,6-8)}$ Thus compound 2 was identified as $6 \alpha-$ acetoxy-9 $\beta$-benzoyloxy- $1 \beta$-cinnamoyloxy- $8 \beta$-(2-methylbutanoyloxy)- $\beta$-dihydroagarofuran.

Compound $6, \mathrm{C}_{31} \mathrm{H}_{36} \mathrm{O}_{8}$, contained one hydroxyl, one acetoxy, and two benzoyloxy groups as shown by its ${ }^{1} \mathrm{H}-,{ }^{13} \mathrm{C}$ NMR, and MS spectra. the chemical shifts and coupling pattern assignable to $\mathrm{H}-6, \mathrm{H}-7, \mathrm{H}-8$ and $\mathrm{H}-9$ in the ${ }^{1} \mathrm{H}-$ and ${ }^{13} \mathrm{C}-$ NMR spectra of $\mathbf{6}$ were very similar to those of the known compounds $6 \alpha$-acetoxy- $8 \beta, 9 \beta$-dibenzoyloxy- $1 \beta$-hydroxy- $\beta$ dihydroagarofuran, and $6 \alpha$-acetoxy $-1 \beta, 9 \beta$-dibenzoyloxy- $8 \beta$ hydroxy- $\beta$-dihydroagarofuran reported in the literature. ${ }^{3,9}$ ) The substituted group distribution in $\mathbf{6}$ was confirmed from the HMBC spectrum, which indicated cross peaks between H-6 $[\delta 6.04(1 \mathrm{H}, \mathrm{s})]$ and the carbonyl $(\delta 169.9)$ of acetoxy, $\mathrm{H}-1[\delta 5.56(1 \mathrm{H}, \mathrm{dd}, J=10.8,5.0 \mathrm{~Hz})]$ and the carbonyl $(\delta$ 166.2) of benzoyloxy, and $\mathrm{H}-8[\delta 5.59(1 \mathrm{H}, \mathrm{dd}, J=5.0$, $4.2 \mathrm{~Hz}$ ) ] and the carbonyl ( $\delta 166.2)$ of benzoyloxy, respectively. Therefore one acetoxy situated at C-6 and two benzoyloxy groups and hydroxy were at C-1, C-8, and C-9, respectively. In the NOESY spectrum, cross peaks between $\mathrm{H}-1$ and H-9, and H-8 and H-9 suggested that compound 6 has the same relative stereochemistry as compounds $\mathbf{1}$ and $\mathbf{2}$. Thus compound 6 was elucidated to be $6 \alpha$-acetoxy- $1 \beta, 8 \beta$-dibenzoyloxy- $9 \beta$-hydroxy- $\beta$-dihydroagarofuran.

Compounds $1-\mathbf{6}$ were examined for their dose-response effects against LPS-induced NO production. The excess production of NO by iNOS in macrophages and endothelial cells is responsible for the inflammatory response and implicated in the pathogenesis of several inflammatory diseases such as septic shock, rheumatoid arthritis, graft rejection, and diabetes. ${ }^{10)}$ The effects of compounds $\mathbf{1}-\mathbf{6}$ were investigated on NO production in LPS-stimulated RAW264.7 cells with re- spect to aminoguanidine, an iNOS inhibitor. Compound 4 showed moderate inhibitory activity against LPS-induced NO production in murine macrophage RAW264.7 cells, with an $\mathrm{IC}_{50}$ value of $43.7 \mu \mathrm{M}$, which is comparable to that of aminoguanidine ( $\mathrm{IC}_{50} 18.2 \mu \mathrm{M}$ ). However, compounds $\mathbf{1}, \mathbf{2}, \mathbf{3}$, $\mathbf{5}$, and $\mathbf{6}$ showed very weak activity. Cell viability measured using the MTT assay showed that compound $\mathbf{4}$ had no significant cytotoxicity against RAW264.7 cells at effective concentrations for the inhibition of NO production (data not shown).

\section{Experimental}

Melting points were measured on a Yamaco hot-stage and are uncorrected. All NMR spectra were recorded on Bruker-ARX-300 spectrometer, using TMS as an internal standard. UV spectra were recorded on a Shimadzu UV-260 UV-Vis spectrometer. ESI-MS were measured on a VG70SE mass spectrometer. Optical rotations were measured on a Perkin-Elmer 241 polarimeter. Silica for chromatography was produced by Qingdao Ocean Chemical Group Co., China. The HPLC system used a Shimadzu CTO-6A equipped with a Shimadzu SPD-6A UV detector (Shimadzu Shim-pack PREP-ODS, i.d. $2.5 \times 21.6 \mathrm{~cm}$ ).

Plant Material The plant material was collected in Shenyang, Liaoning province, and was identified by Professor Guo Yunzheng (Shenyang Pharmaceutical University).

Extraction and Isolation Dried fruits $(10 \mathrm{~kg})$ of C. orbiculatus were extracted with $95 \%$ ethanol. The extract was concentrated and then extracted successively with petroleum ether, $\mathrm{CHCl}_{3}$, EtOAc and $n$ - $\mathrm{BuOH}$. The petroleum ether fraction $(160 \mathrm{~g})$ was subjected to column chromatography on silica gel and eluted with petroleum ether-acetone $(100: 0-1: 1)$ to provide seven fractions. Fraction 3 ( $4.7 \mathrm{~g}$ ) was subjected by column chromatography on HPLC to yield compounds 1 ( $7 \mathrm{mg}, 90 \mathrm{~min}), \mathbf{2}(5 \mathrm{mg}, 110 \mathrm{~min}), \mathbf{4}(4 \mathrm{mg}$, $73 \mathrm{~min}$ ), and $5(4 \mathrm{mg}, 51 \mathrm{~min})$ using $\mathrm{MeOH}-\mathrm{H}_{2} \mathrm{O}(78: 22)$ as eluent, and fraction $4(5.1 \mathrm{~g})$ was subjected to column chromatography on HPLC to yield compounds 3 (4 mg, $41 \mathrm{~min})$ and $6(5 \mathrm{mg}, 64 \mathrm{~min})$ using $\mathrm{MeOH}-\mathrm{H}_{2} \mathrm{O}$ $(75: 25)$ as eluent.

Compound 1: White powder (EtOAc), mp $181-183^{\circ} \mathrm{C}$. UV $\lambda_{\max }$ $(\mathrm{MeOH}): 223.0 \mathrm{~nm} .[\alpha]_{\mathrm{D}}=-7.0^{\circ} \quad(c=0.75, \mathrm{MeOH})$. ESI-MS: $m / z 633$ $[\mathrm{M}+\mathrm{H}]^{+}$, HR-MS: $m / z 633.3070[\mathrm{M}+\mathrm{H}]^{+}\left(\right.$Calcd for $\left.\mathrm{C}_{37} \mathrm{H}_{45} \mathrm{O}_{9}, 633.3064\right)$. ${ }^{1} \mathrm{H}-\mathrm{NMR}\left(\mathrm{CDCl}_{3}, 300 \mathrm{MHz}\right)$ see Table 1, acetoxy [2.12 (3H, s)]. Benzoyloxy and cinnamoyloxy $[5.73(1 \mathrm{H}, \mathrm{d}, J=15.9 \mathrm{~Hz}), 6.91-7.91(11 \mathrm{H}, \mathrm{m})]$, butanoyloxy $[0.88(3 \mathrm{H}, \mathrm{t}, J=14.7,7.5 \mathrm{~Hz}), 1.66(2 \mathrm{H}, \mathrm{m}), 2.37(2 \mathrm{H}, \mathrm{t}$, 
$J=7.5 \mathrm{~Hz})] \cdot{ }^{13} \mathrm{C}-\mathrm{NMR}\left(\mathrm{CDCl}_{3}, 75 \mathrm{MHz}\right)$ see Table 1 , acetoxy $(21.3,169.9)$, benzoyloxy $(164.9,132.6,129.8,129.5,128.2)$, cinnamoyloxy (166.1, $144.2,134.2,129.9,128.3,127.8,118.1)$, butanoyloxy $(172.4,36.4,18.3$, 13.7)

Compound 2: White powder (EtOAc), mp $231-233^{\circ} \mathrm{C}$. UV $\lambda_{\text {max }}$ $(\mathrm{MeOH}): 223.2 \mathrm{~nm} . \quad[\alpha]_{\mathrm{D}}=-8.9^{\circ}(c=0.40, \mathrm{MeOH})$. ESI-MS: $m / z 647$ $[\mathrm{M}+\mathrm{H}]^{+}$, HR-MS: $m / z 647.3220[\mathrm{M}+\mathrm{H}]^{+}$(Calcd for $\mathrm{C}_{38} \mathrm{H}_{47} \mathrm{O}_{9}, 647.3227$ ). ${ }^{1} \mathrm{H}-\mathrm{NMR}\left(300 \mathrm{MHz}\right.$, in $\left.\mathrm{CDCl}_{3}\right)$ see Table 1 , acetate $[2.15(3 \mathrm{H}, \mathrm{s})]$; 2methylbutanoyloxy $[0.79(3 \mathrm{H}, \mathrm{t}), 1.16(3 \mathrm{H}, \mathrm{d}, J=7.0 \mathrm{~Hz}), 1.49(2 \mathrm{H}, \mathrm{m}), 2.41$ $(1 \mathrm{H}, \mathrm{m})]$; benzoyloxy and cinnamoyloxy $[5.73(1 \mathrm{H}, \mathrm{d}, J=15.9 \mathrm{~Hz}), 6.92$ $7.92(11 \mathrm{H}, \mathrm{m})] ;{ }^{13} \mathrm{C}-\mathrm{NMR}\left(75 \mathrm{MHz}\right.$, in $\left.\mathrm{CDCl}_{3}\right)$ see Table 1 , acetoxy $(21.3$, 169.8); 2-methylbutanoyloxy (175.2, 41.6, 26.6, 11.6, 16.4); benzoyloxy $(164.8,132.6,129.8,129.6,128.2)$, cinnamoyloxy $(166.1,144.2,134.2$, $129.8,128.3,127.9,118.1)$

Compound 6: White powder (EtOAc), mp $217-219^{\circ} \mathrm{C}$. UV $\lambda_{\text {max }}$ $(\mathrm{MeOH}): 227.0 \mathrm{~nm} .[\alpha]_{\mathrm{D}}=-286^{\circ}(c=0.70, \mathrm{MeOH})$. ESI-MS: $m / z 537$ $[\mathrm{M}+\mathrm{H}]^{+}$, HR-MS: $m / z 537.2436[\mathrm{M}+\mathrm{H}]^{+}\left(\right.$Calcd for $\left.\mathrm{C}_{31} \mathrm{H}_{37} \mathrm{O}_{8}, 537.2488\right)$ ${ }^{1} \mathrm{H}-\mathrm{NMR}\left(\mathrm{CDCl}_{3}, 300 \mathrm{MHz}\right)$ see Table 1 , acetoxy [2.09 $\left.(3 \mathrm{H}, \mathrm{s})\right]$, benzoyloxy [7.35-8.14 $(10 \mathrm{H}, \mathrm{m})],{ }^{13} \mathrm{C}-\mathrm{NMR}\left(\mathrm{CDCl}_{3}, 75 \mathrm{MHz}\right)$ see Table 1 , acetoxy (21.2, 169.9), benzoyloxy $(166.2,166.2,133.1,132.7,129.7,129.4,128.5$, 128.3).

Determination of NO Production RAW264.7 cells were transferred to 96-well plates at a density of $1 \times 10^{5}$ cells/well. After 3 -h incubation, the cells were stimulated with LPS $(1 \mu \mathrm{g} / \mathrm{ml})$ for $24 \mathrm{~h}$ in the presence or absence of the compounds tested. As a parameter of NO synthesis, nitrite concentration was measured in the supernatant of RAW264.7 cells with the Griess reaction. ${ }^{11)}$ Briefly, $100 \mu \mathrm{l}$ of cell culture supernatant was reacted with $100 \mu \mathrm{l}$ of Griess reagent [1:1 mixture of $0.1 \% N$-(1-naphthyl)ethylenediamine in $\mathrm{H}_{2} \mathrm{O}$ and $1 \%$ sulfanilamide in $5 \%$ phosphoric acid] in a 96-well plate, and absorbance was read with a microplate reader (Molecular Devices Co., Menlo Park, CA, U.S.A.) at $570 \mathrm{~nm}$. The nitrite concentration in the super- natants was calculated by comparison with a sodium nitrite standard curve.

Acknowledgments Special thanks are due to the Analytical Center, Shenyang Pharmaceutical University, for recording UV, ESI-MS, and NMR spectra. We are also grateful to Professor Yunzheng Guo for plant identification.

\section{References}

1) Jiangsu New Medicinal College, "Dictionary of Chinese Herbal Medicine,” Vol. 2, Shanghai People,s Publishing House, Shanghai, 1977, p. 1563 .

2) Jin H. Z., Hwang B. Y., Kim H. S., Lee J. H., Kim Y. H., Lee J. J., J. Nat. Prod., 65, 89-91 (2002).

3) Takaishi Y., Ohshima S., Nakano K., Tomimatsu T., Tokuda H., Nishino H., Iwashima A., J. Nat. Prod., 56, 815-824 (1993).

4) Wang M. A., Chen F. H., Chin. Chem. Lett., 6, 229-230 (1995).

5) Wu D. G., Liu J. K., Chen C. Q., Phytochemistry, 31, 4219-4222 (1992).

6) Tu Y. Q., Hu Y. J., Wu W. J., Chen N. Y., Pan X. F., Phytochemistry, 31, 3633-3634 (1992).

7) Bruning K., Wagner H., Phytochemistry, 17, 1821-1858 (1978).

8) Takaishi Y., Tokura K., Tamai S., Ujita K., Nakano K., Tomimatsu T., Phytochemistry, 30, 1567-1572 (1991).

9) Takaishi Y., Noguchi H., Murakami K., Nakano K., Tomimatsu T., Phytochemistry, 29, 3869-3873 (1990).

10) MacMicking J., Xie Q., Nathan C., Annu. Rev. Immuno., 15, 323-350 (1997).

11) Schmidt H. H. H. W., Kelm M., "Methods in Nitric Oxide Research," Chapter 33, ed. by Feelish M., Stamler J., John Wiley \& Sons Ltd., New York, 1996, pp. 491-497. 